\title{
Monitoring the effect of conservation practices on the erosion rates in some small watersheds in Eastern Romania
}

\author{
Nelu Popa *, Dumitru Nistor, Cosmin Hurjui, Eugen Filiche, Gabriel Petrovici
}

Research and Development Center for Soil Erosion Control Perieni, Vaslui county, Romania

\section{Article Info}

Received : 15.07.2014

Accepted : 21.11.2014

\begin{abstract}
It is known that the successful implementation of control measures to preserve soil quality on slope agricultural lands depends largely on the designer's ability to select a control strategy for a specific site, considerable simpler and less costly. The paper refers to several small watersheds with agricultural use, representative for Eastern hilly area of Romania, where different types of soil conservation measures have been applied. The study included monitoring of some factors to highlight the role of soil conservation practices in reducing water erosion process. In this respect, it was studied the dynamics of the climatic, pedological, relief, vegetation, hydrology and erosion parameters. Runoff and erosion rates for individual storms were studied both at the plot and microbazin level by performing measurements on standard runoff plots, respectively in the network flow sections. Also, RUSLE model and Geographic Information System were used to simulate spatial distribution of erosion and sedimentation processes. Significant interactions and feedbacks were found to occur between soil characteristics and vegetation, which influenced both runoff and erosion responses. Monitoring allowed more direct linkages to be made between management practices and their impacts on runoff and soil erosion.
\end{abstract}

Keywords: soil erosion, runoff plots, conservation practices

(C) 2015 Federation of Eurasian Soil Science Societies. All rights reserved

\section{Introduction}

Land use and management are the result of human activities and are the most important factors that influence soil erosion. Regional soil erosion assessment is needed in order to make objective comparisons that may provide a basis for further environmental analysis, economic statements or policy development, to formulate suitable remediation measures and mitigation strategies.

Some methods for carrying out regional assessment are based on the collection of distributed field observations and others on an assessment of factors, and combinations of factors, which influence erosion rates.

Monitoring the effect of conservation practices on the erosion rates and measuring campaigns may lead to new insights and therefore to both better mapping and risk assessments.

\footnotetext{
${ }^{*}$ Corresponding author.

Research and Development Center for Soil Erosion Control Perieni, 731248 Barlad, PO Box 1, Vaslui county, Romania

Tel.: +40373550155

E-mail address: nelu_c_popa@yahoo.com

ISSN: $2147-4249$
} 


\section{Material and Methods}

\section{Study Site}

Selection of study areas concerning the behavior of conservation practices has been based on the achievement of some conditions. The first was that the area should be representative for the study area and representativeness referred to the type of farm, landscape, climate and soil. A second condition was that the chosen area had to have a set of measures and conservation practices. They will be further enhanced by the will of landholders and the funds that can be attracted. Another important requirement was the ability to monitor the parameters that define the quality of planning and farming. The study area must be accessible during rainy periods and located at a distance allowing a one day visit of the team carrying out the field observations and measurements. Finally, three areas from Barlad Tableland, Eastern Romania (Figure 1), were selected: Tărnii Valley, Gheltag basin and Ghilahoi basin.

Study area from Tărnii Valley includes only the upper part of the basin and has an area of approx. 500 ha of state-owned and RDCSEC Perieni administration. The landscape is characterized by long and uniform slopes of $10-13 \%$. The soil is represented by a moderately deep Cambic Chernozem, medium clay loam textured, characterized by moderate erosion.

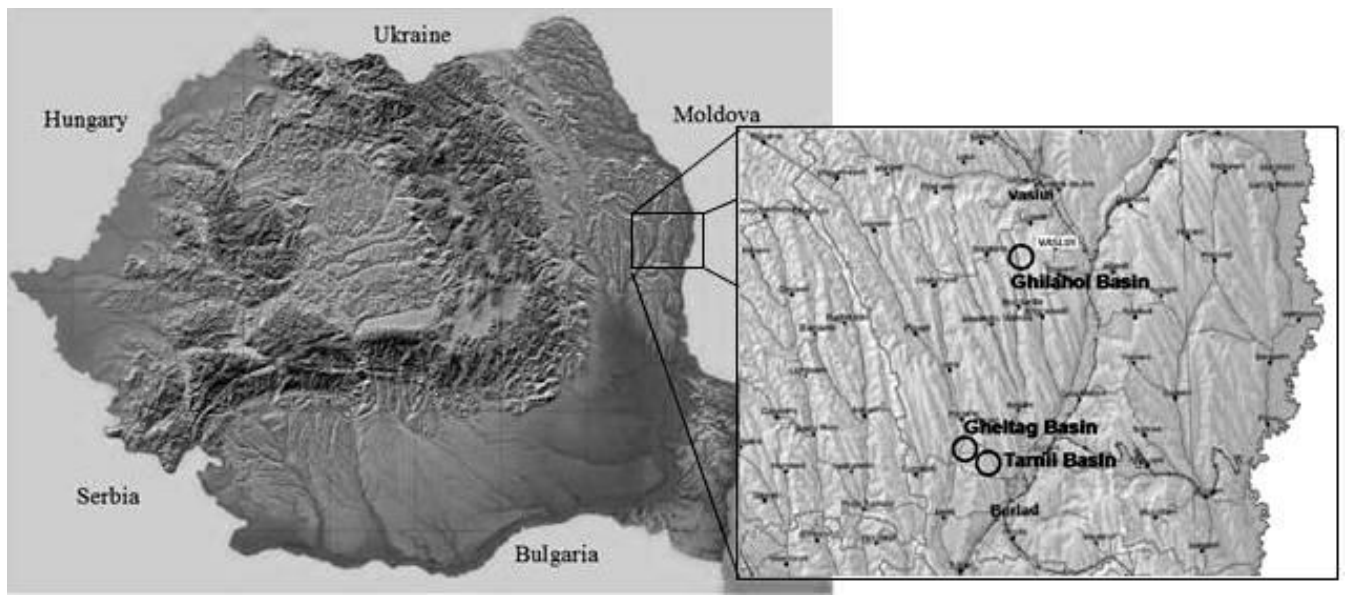

Figure 1. Study areas from Barlad Tableland, Eastern Romania

During the '50s and the '60s the land was arranged in terms of soil erosion control and the following soil conservation measures have been used: contour planting, intercropping, strip cropping, an adequate network of camp roads, a grassed waterway and a drainage network. Two stations provided meteorological data. One of them is located $5 \mathrm{~km} \mathrm{S-E,} \mathrm{in} \mathrm{Barlad} \mathrm{town} \mathrm{and} \mathrm{has} \mathrm{recorded} \mathrm{data} \mathrm{since} \mathrm{1941.} \mathrm{The} \mathrm{other} \mathrm{one} \mathrm{is} \mathrm{an}$ automatic weather station and is positioned in the neighborhood of the site, on the territory of Perieni Research Center. The second study area is located in Gheltag basin, with gentle to hilly slopes and the soil is represented by gray forest soil, highly eroded. The terrain that has almost 100 ha arable land was fit out by different conservation measures in the period of 1975-1977 when it belonged to the State.

After the Romanian revolution in 1989, according to the new laws on land property, the entire area of Gheltag basin was reallotted to 83 previous landowners, on the original locations that meant the plots consisted of long and narrow strips, arranged on the up-and-down hill direction. This situation made impossible the application of the contour tillage system and led to the abandonment of the majority of conservation practices. Since 2002 the terrain was leased by Perieni Research Center and was completely rehabilitated. The following soil conservation measures were used: intercropping, contour planting, strip cropping, bench terraces, a grassed waterway and a drainage network.

Finally, the third study area is located in the basin Ghilahoi and comprises approx. 750 ha privately owned. The land extends over several microbasins with slopes ranging between 5 and $14 \%$ and was divided into small long and narrow downslope oriented parcels. Documentary study and field observations showed that in the period of $1991-2006$ a subsistence agriculture was practiced on this land. Since 2006 the land was leased by SC Plantagro Com SRL, which created favorable conditions for the introduction of appropriate soil conservation practices and a modern type of agriculture. It is appreciated that all experimental perimeters described above are representative of the studied area both in terms of topography, climate and soil as well as in terms of the type of land ownership. 


\section{Experimental Methods}

In Tarnii Valley the research was conducted on eight conventional runoff plots, fully instrumented for measuring runoff and soil loss under different conditions concerning vegetative cover and have been used since 1985. Six of them have a surface of $100 \mathrm{~m}^{2}(25 \mathrm{x} 4 \mathrm{~m})$ and the other two have $150 \mathrm{~m}^{2}(37.5 \times 4 \mathrm{~m})$. The plots were cultivated with different crops like winter wheat, corn, beans, soybeans and Bromus and two check plots of 100 and $150 \mathrm{~m}^{2}$ were maintained as black fallow (Figure 3). Following a conventional mehod, both sediments and water coming from each plot were collected in calibrated tanks from which samples were taken for laboratory analysis of turbidity, nutrient content and other chemical properties.

The monitoring of hydrological response of studied areas was performed in some control sections by means of two short-crested triangular weirs. This weir type (Figure 2) was developed by Natural Resources Conservation Service - US Department of Agriculture (Brakensiek et al., 1979).

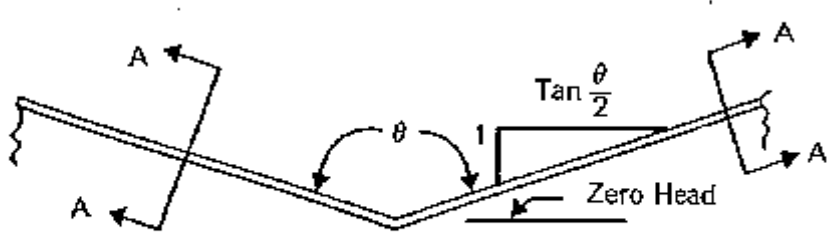

Elevation

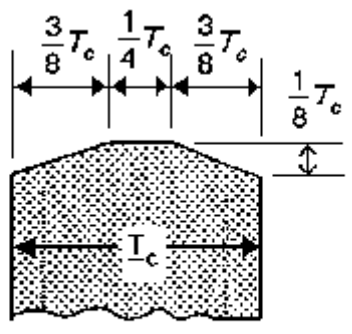

Section A-A

Figure 2. Short - crested triangular weir

The discharge equation for the short - crested triangular weir is the following:

$$
Q=\left(C_{0}+C_{1} \log _{10} \frac{h}{T_{c}}\right) \sqrt{g} \tan \frac{\theta}{2}\left(h+\alpha \frac{v^{2}}{2 g}\right)^{2.5}
$$

$\theta=157^{\circ}$ for Tarnii Valley and $\theta=150^{\circ}$ for Gheltag

$\propto=1.33$

$\mathrm{v}=$ average velocity in cross section $3 \mathrm{~m}$ upstream from center of crest;

$\mathrm{h}=$ head $3 \mathrm{~m}$ upstream from center of crest;

$\mathrm{T}_{\mathrm{c}}=$ crest thickness $(0.4 \mathrm{~m})$;

$\mathrm{C}_{0}, \mathrm{C}_{1}=$ correction factors.

In Tarnii Valley the weir was constructed during 2012 (Figure 4) at the bottom of the valley in a location that controls 337 ha from the total of 500 ha, while in Gheltag basin the check dam controls about 85 ha from 100 ha.

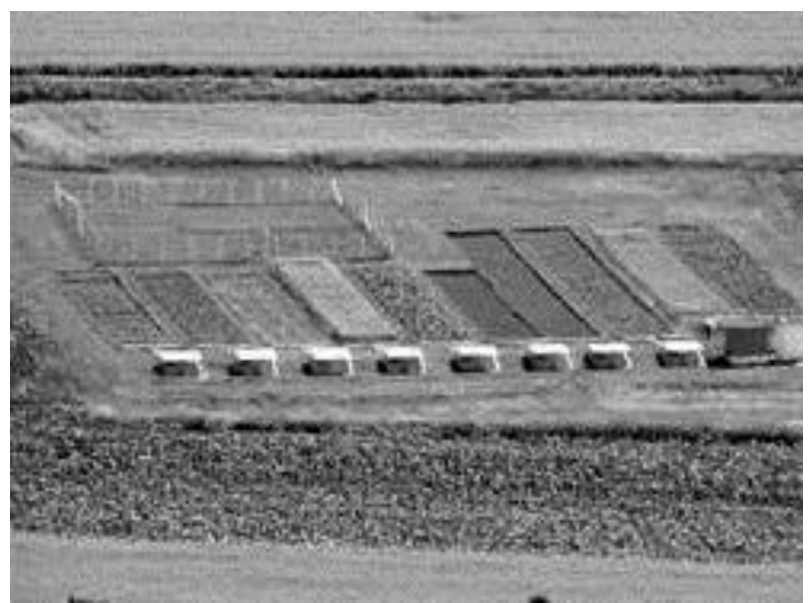

Figure 3. Runoff plots from RDCSEC Perieni, Romania

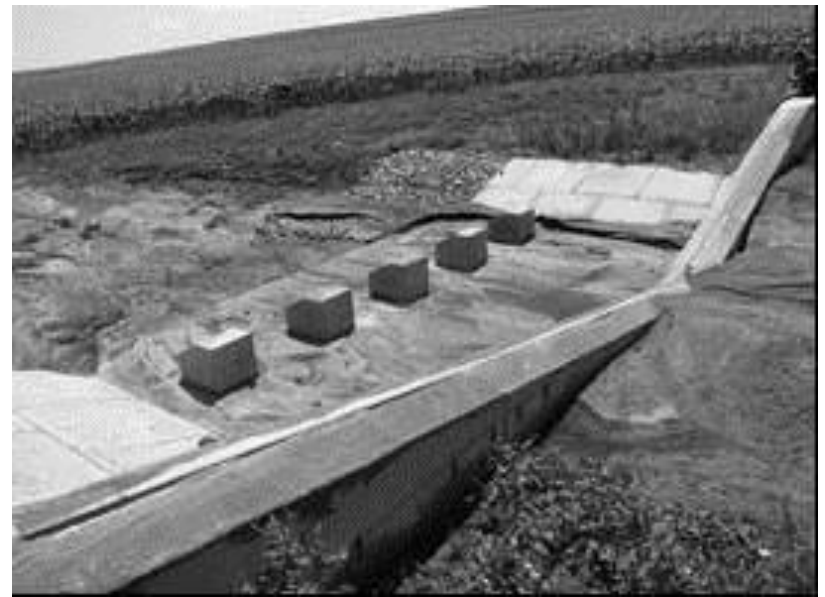

Figure 4. Control section from Tarnii Valley 
Soil moisture was considered among the physical parameters of soil that are very important for soil tillage and especially, for the vegetation growth and finally for the level of agricultural yield. In Tărnii Valley variation of the soil moisture has been studied along a cross section through the entire basin, which has 21 drilling holes having depths of $100 \mathrm{~cm}$, and soil samples were taken at $10 \mathrm{~cm}$ intervals, for various crops.

Finally, the revised universal soil erosion equation (RUSLE) module within the IDRISI Andes software was used to determine the spatial pattern of soil loss in Tarnii Valley.

The RUSLE module required six factors (Renard et.al. 1997), represented by the following equation:

$$
\mathrm{A}=\mathrm{R} \bullet \mathrm{K} \bullet \mathrm{L} \bullet \mathrm{S} \bullet \mathrm{C} \bullet \mathrm{P}
$$

Where A is computed soil loss per unit area (to/ha/y), $\mathrm{R}$ is the factor for annual rainfall erosivity, $\mathrm{K}$ is the soil erodibility factor, $\mathrm{L}$ is the slope-length factor, $\mathrm{S}$ is the slope-steepness factor, $\mathrm{C}$ is the cover and management factor and P is the support practice factor (Foster et. al. 1981; Hudson 1993; Toit et al., 2002; Wischmeier et al., 1978). In this purpose, the digital elevation model and the map layers corresponding to $R, K, C$ and $P$ parameters have been developed. It has been taken into account the recommendation from Idrisi manual that slope length should be maximum 400 feet (121.92 meters). That means that the maximum slope length threshold is the distance water can flow as a sheet before becoming concentrated. In our case, a distance of $100 \mathrm{~m}$ was chosen so, the minimum surface area of a parcel calculation was set to $100 \mathrm{~m}^{2}$, this value corresponding to the size of the pixel of digital elevation model for Tarnii Valley.

\section{Results and Discussion}

Studies on runoff plots were made between 1985 and 2013, under natural precipitation, in an area where the average of annual rainfall is $492 \mathrm{~mm}$ and the critical erosion season is between May and August. Having in sight that only 2-3 monthly rainfall triggers significant soil erosion processes, the study had to be conducted for a long period of time to get enough data to give acceptable statistical significance.

Figure 5 shows the frequency analysis for the major crops (corn, winter wheat, beans and bromus) and for the check plots. It is noted that for the plots maintained as black fallow the maximum values of runoff and erosion are the most significant for the rainfall between 10 and $30 \mathrm{~mm}$, as well as for the exceptional rains exceeding $50 \mathrm{~mm}$. For corn, the chart indicates an important decrease by over $70 \%$ of soil losses, although runoff had quite high values. As in the first case, rainfalls higher than $50 \mathrm{~mm}$, although few in number, produced the most important soil losses. For beans, the pattern remains similar to that of corn, except that erosion has somewhat lower values. Finally, the situation for Bromus and winter wheat is completely different from the previous ones, meaning that soil losses are insignificant while runoff is triggered, generally, by rainfall higher than $20 \mathrm{~mm}$.

Comparing the five analyzed cases is it observed that the losses of water and soil according to the frequency of rainfall size are highest for black fallow, less for corn and beans and very uneven for Bromus and winter wheat. This is due to the influence of vegetal cover that is ineffective for black fallow and maximum for winter wheat and Bromus. The winter wheat is most vulnerable during sowing, in late October and early November and offers the best protection against soil erosion in June, before the harvest, when the vegetative mass reaches the maximum value. After harvest, although the degree of protection of winter wheat stubble is lower, only a very large number of rainfalls in July and August makes the runoff have higher values, while soil losses are insignificant. Also, Bromus is the most vulnerable in the first year.

Figure 6 shows the multiyear values of runoff and erosion of the entire period of 29 years for all examined crops. Highest value of erosion, of 40.71 to/ha/year, has been recorded on black fallow, average values of 8,67 and 5,08 to/ha/year for corn, and beans and minimum values of 0,71 and 0.33 for winter wheat and bromegrass. Runoff reflects generally the same pattern in all graphs. 


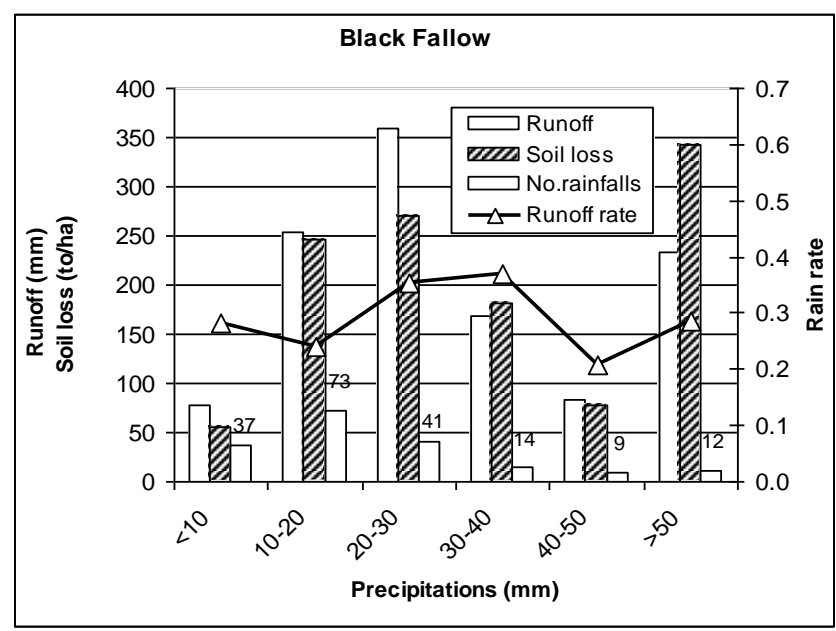

(a)

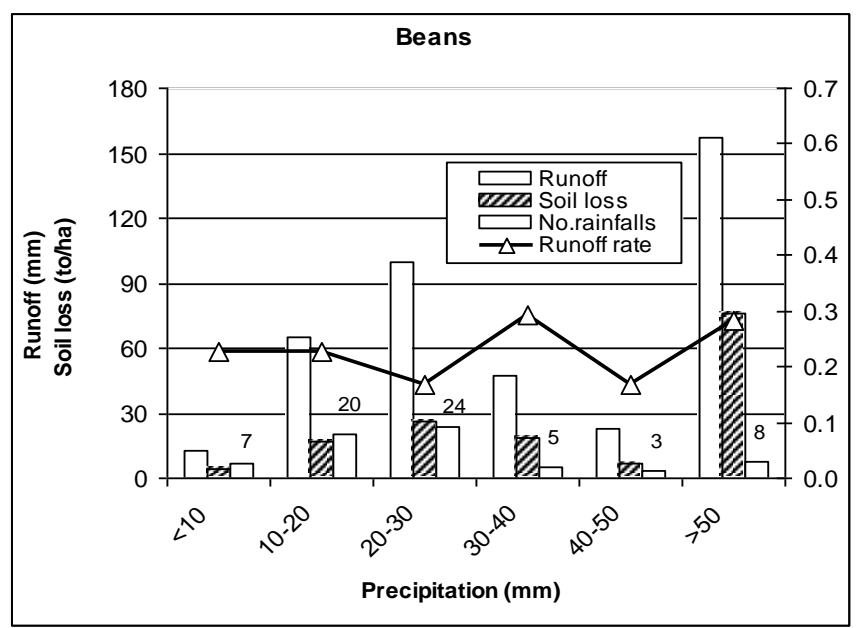

(c)

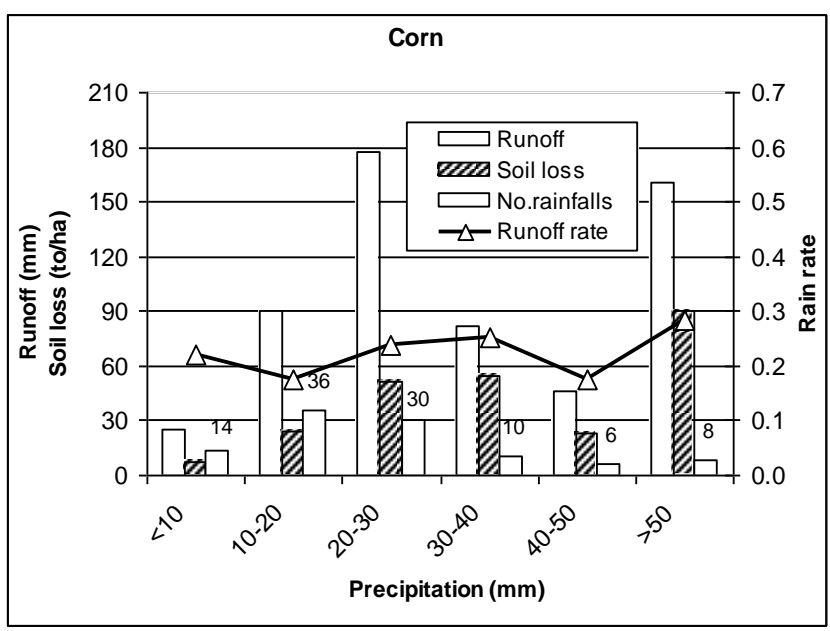

(b)

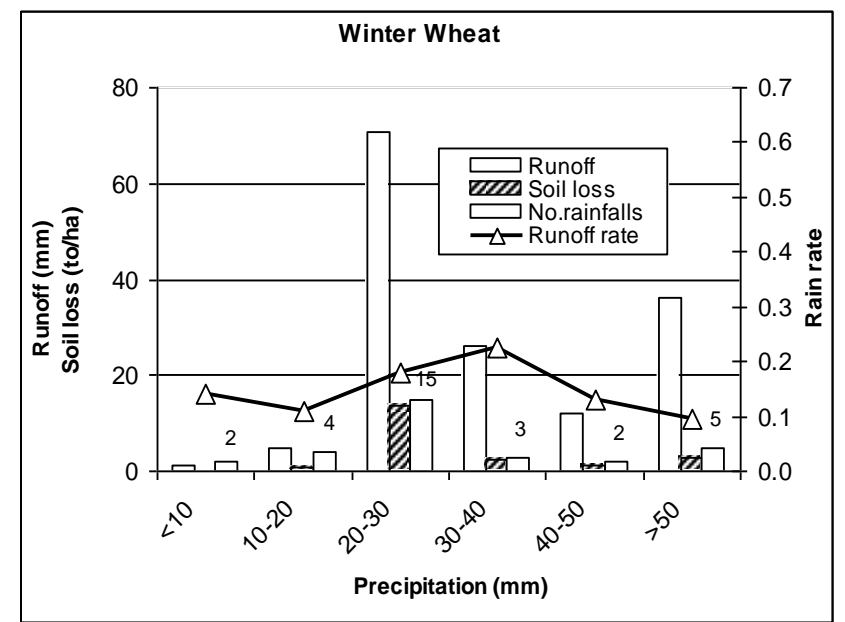

(d)

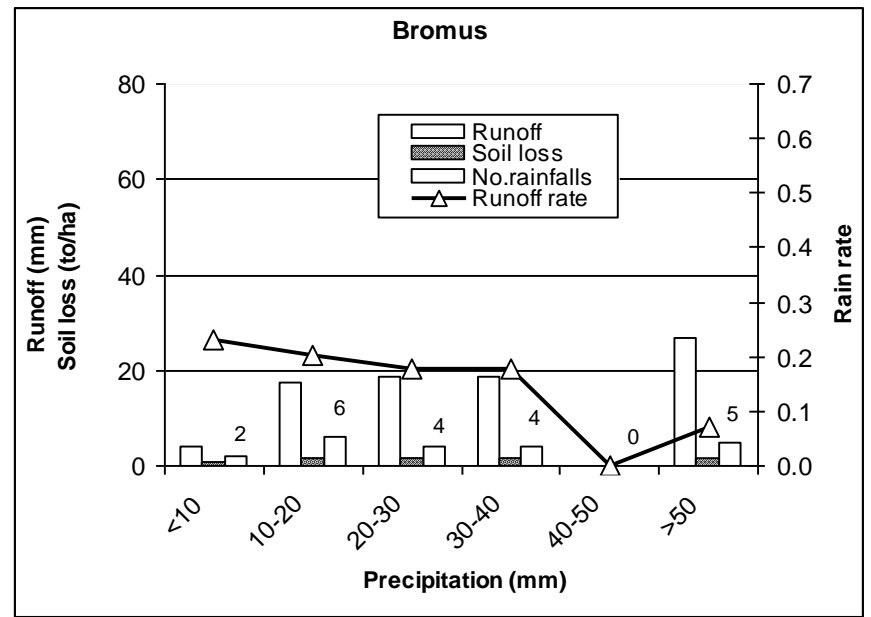

(e)

Figure 5. Frequency of runoff, soil loss and rainfalls which triggered runoff during 1985-2013 for: a) Black fallow, b) Corn, c) Beans, d) Winter Wheat, e) Bromus 


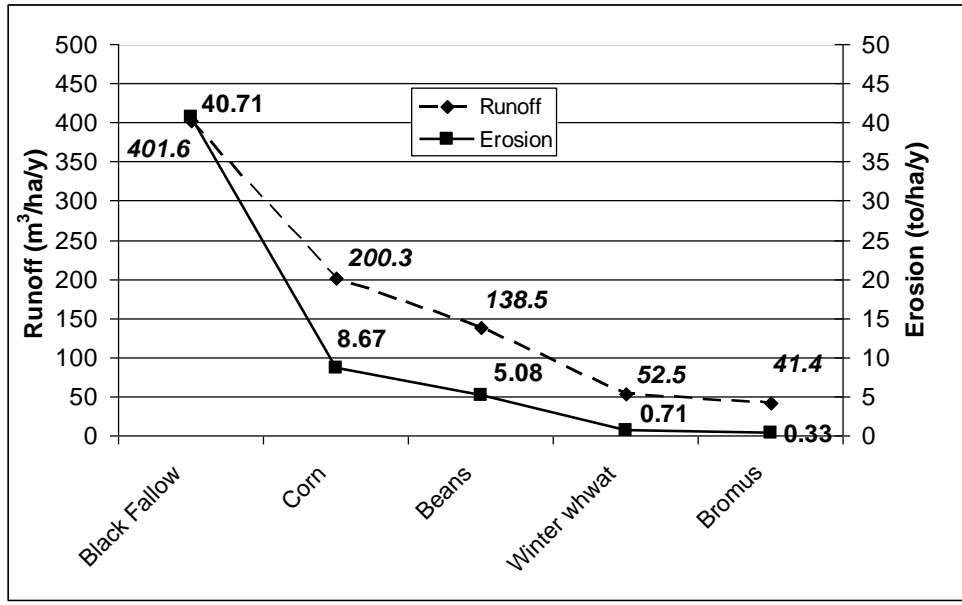

Figure 6. Multiannual average of runoff and soil loss values during 1985-2013

In Table 1, data concerning nutrient losses by runoff and erosion measured between 1985 and 2013 are presented. It can be seen that humus losses ranged from $11.7 \mathrm{Kg} \mathrm{ha}^{-1} \mathrm{year}^{-1}$ for Bromus to $767.8 \mathrm{Kg} \mathrm{ha}^{-1} \mathrm{year}^{-1}$ for black fallow. Also, the amount of the total nitrogen losses increases as crops have a lower coefficient of land cover. However, its percentage decreases in runoff more than in eroded soil, from $21.2 \%$ for black fallow to $2.6 \%$ for Bromus plot. The same trend is observed for phosphorus losses, except that of the percentage of water loss, which is somewhat higher.

If it is found that the potassium losses in water is $73.5 \%$ for Bromus, while for black fallow, reach $20.3 \%$.

Table 1. Nutrient losses by runoff and erosion measured between 1985 and 2013

\begin{tabular}{lcccc}
\hline \multirow{2}{*}{ Crop } & \multirow{2}{*}{$\begin{array}{c}\text { Numus } \\
\mathrm{Kg} \mathrm{ha}^{-1} \mathrm{y}^{-1}\end{array}$} & $\begin{array}{c}\text { Total } \\
\mathrm{Kg} \mathrm{ha}^{-1} \mathrm{y}^{-1}\end{array}$ & $\begin{array}{c}\text { in water } \\
\%\end{array}$ & $\begin{array}{c}\text { in soil } \\
\%\end{array}$ \\
\cline { 3 - 5 } & 767.232 & 39.773 & 2.61 & 97.39 \\
Black Fallow & 156.579 & 8.340 & 7.24 & 92.76 \\
Corn & 103.172 & 5.729 & 7.67 & 92.33 \\
Beans & 15.412 & 0.923 & 11.78 & 88.22 \\
Winter wheat & 11.703 & 0.962 & 21.21 & 78.79 \\
Bromus & &
\end{tabular}

Table 1. -continued

\begin{tabular}{lcccccc}
\hline \multirow{3}{*}{ Crop } & \multicolumn{3}{c}{$\mathrm{K}_{2} \mathrm{O}$} & \multicolumn{3}{c}{$\mathrm{P}_{2} \mathrm{O}_{5}$} \\
\cline { 2 - 7 } & $\begin{array}{c}\text { Total } \\
\left(\mathrm{Kg} \mathrm{ha}^{-1} \mathrm{y}^{-1}\right)\end{array}$ & $\begin{array}{c}\text { In water } \\
(\%)\end{array}$ & $\begin{array}{c}\text { In soil } \\
(\%)\end{array}$ & $\begin{array}{c}\text { Total } \\
\left(\mathrm{Kg} \mathrm{ha}^{-1} \mathrm{y}^{-1}\right)\end{array}$ & $\begin{array}{c}\text { In water } \\
(\%)\end{array}$ & $\begin{array}{c}\text { In soil } \\
(\%)\end{array}$ \\
\hline Black Fallow & 6.710 & 20.31 & 79.69 & 2.120 & 17.29 & 82.71 \\
Corn & 1.899 & 41.90 & 58.10 & 0.742 & 31.08 & 68.92 \\
Beans & 1.296 & 46.21 & 53.79 & 0.466 & 33.05 & 66.95 \\
Winter wheat & 0.399 & 72.78 & 27.22 & 0.188 & 72.95 & 27.05 \\
Bromus & 0.302 & 73.53 & 26.47 & 0.121 & 51.73 & 48.27 \\
\hline
\end{tabular}

Figure 7 shows the graph of monthly precipitation dynamics and soil water storage at the depth of $30 \mathrm{~cm}$, for different crops from Tarnii Valley, between March and October 2013. It is revealed that the water storage has two peaks: one in June and the other in September when rainfall exceeded by $30 \%$ the average monthly precipitation.

Monitoring of hydrological response of Tarnii Valley basin has been related to the crop structure which was in 2013 as follows:

- $\quad 42.8$ ha cultivated by row crops (corn, sun flower, sorghum, soybeans);

230 ha covered by cereals (winter wheat and barley);

51 ha perennial grasses (alfalfa and Dactilis);

Also, there were taken into account 10 ha of shelter belts and 4 ha of camp roads. 


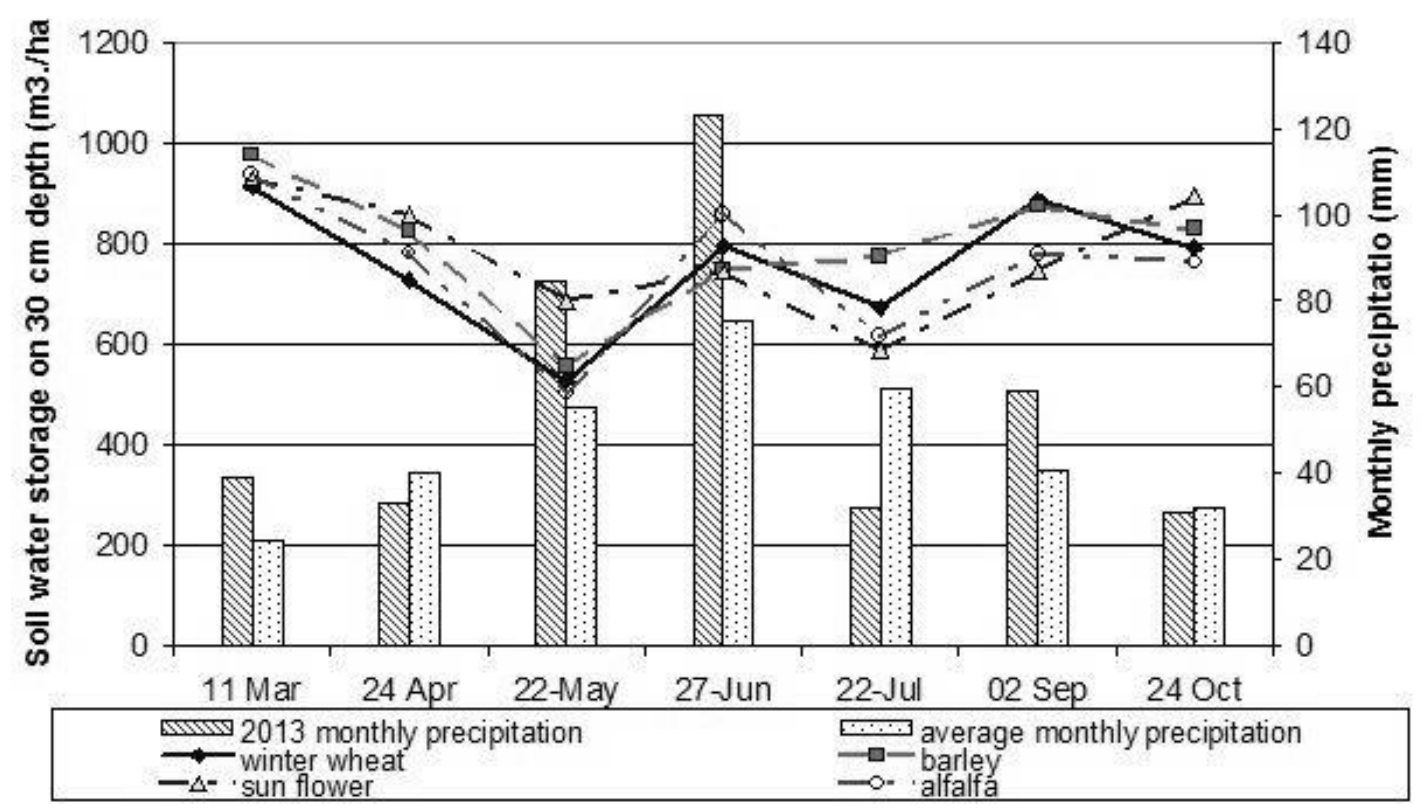

Figure 7. Monthly precipitation dynamics and soil water storage on the depth of $30 \mathrm{~cm}$ in Tarnii Valley, in warm season 2013

In 2013 two important rainfall events that triggered erosion processes were studied: on May 23 when the rainfall reached $35.5 \mathrm{~mm}$, and on June 8 with a rainfall of $30.0 \mathrm{~mm}$.

At the time of rainfall from May 23, field observations showed that the raw crops were in the early stage of growth. It was also noticed that on areas with gentle to rolling slopes, the most important rills were caused by the pattern of the microrelief formed many years ago, when the tillage was usually executed following the up-and-down hill direction. Even today, where contour cropping and strip cropping systems are applied, the former microwaves still exist.

In Gheltag basin the situation was somewhat different because the crop structure was as follows: 13.8 ha row crops, 37 ha - winter wheat, 12.3 ha forage crops, 21.4 ha - forest and 0.9 ha - camp roads.

Table 2 presents maximum values of runoff registered on short - crested triangular weirs, volume of water that passed through the control section, runoff rate, total amount of eroded soil that came into the torrential network, and effluent erosion.

Table 2. Runoff and erosion estimated in the control sections from Tarnii Valley and Gheltag

\begin{tabular}{lccccc}
\hline & Qmax & V & Runoff rate & E & Eefl \\
\hline Day of the rain & $\left(\mathrm{m}^{3} / \mathrm{s}\right)$ & $\left(\mathrm{m}^{3}\right)$ & & (to) & (to/ha) \\
\hline 23 May & & Tarnii Valley & 0.36 \\
8 June & 4.62 & 5200 & 0.043 & 120 & 0.17 \\
\hline \multicolumn{7}{l}{ 23 May } & 1.41 & 1800 & 0.018 & 56 & 0.41 \\
8 June & 1.29 & 1650 & Gheltag basin & 0.26 \\
\hline
\end{tabular}

It can be seen that although the two rainstorms were torrentially similar, data about runoff and erosion showed that values were about two to three times lower for the rainstorm in June 8, compared to that of May 23. This is because higher vegetation in June has played an important role in mitigating the erosion processes.

Figure 8 shows the distribution of erosion in Tarnii Valley calculated by RUSLE module of Idrisi Andes software. As shown above, the map is the result of calculation from horizons corresponding to $\mathrm{R}, \mathrm{K}, \mathrm{C}$ and $\mathrm{P}$ 
parameters. R factor for annual rainfall erosivity was calculated for the period 2004-2013 based on records made by the weather station from RDCSEC Perieni and its value was $878 \mathrm{MJ} \cdot \mathrm{mm} / \mathrm{ha} \cdot \mathrm{h}$. Also, the K factor was calculated based on the RDCSEC Perieni Soil Survey performed by OSPA Iasi in 1991. It was found that in $81.4 \%$ of the corresponding basin Tarnii Valley there is a medium loamy soil texture, $9.5 \%$ of the area has a clay loam soil texture, $6.7 \%$ is sandy loam and $2.4 \%$ sandy-loam texture. For each of these types of soils, values of $\mathrm{K}$ were calculated. Depending on crops, $\mathrm{C}$ values ranged between 0.001 and 0.62 and $\mathrm{P}$ values varied from 0.25 to 1.0 corresponding to adopted soil conservation measures.

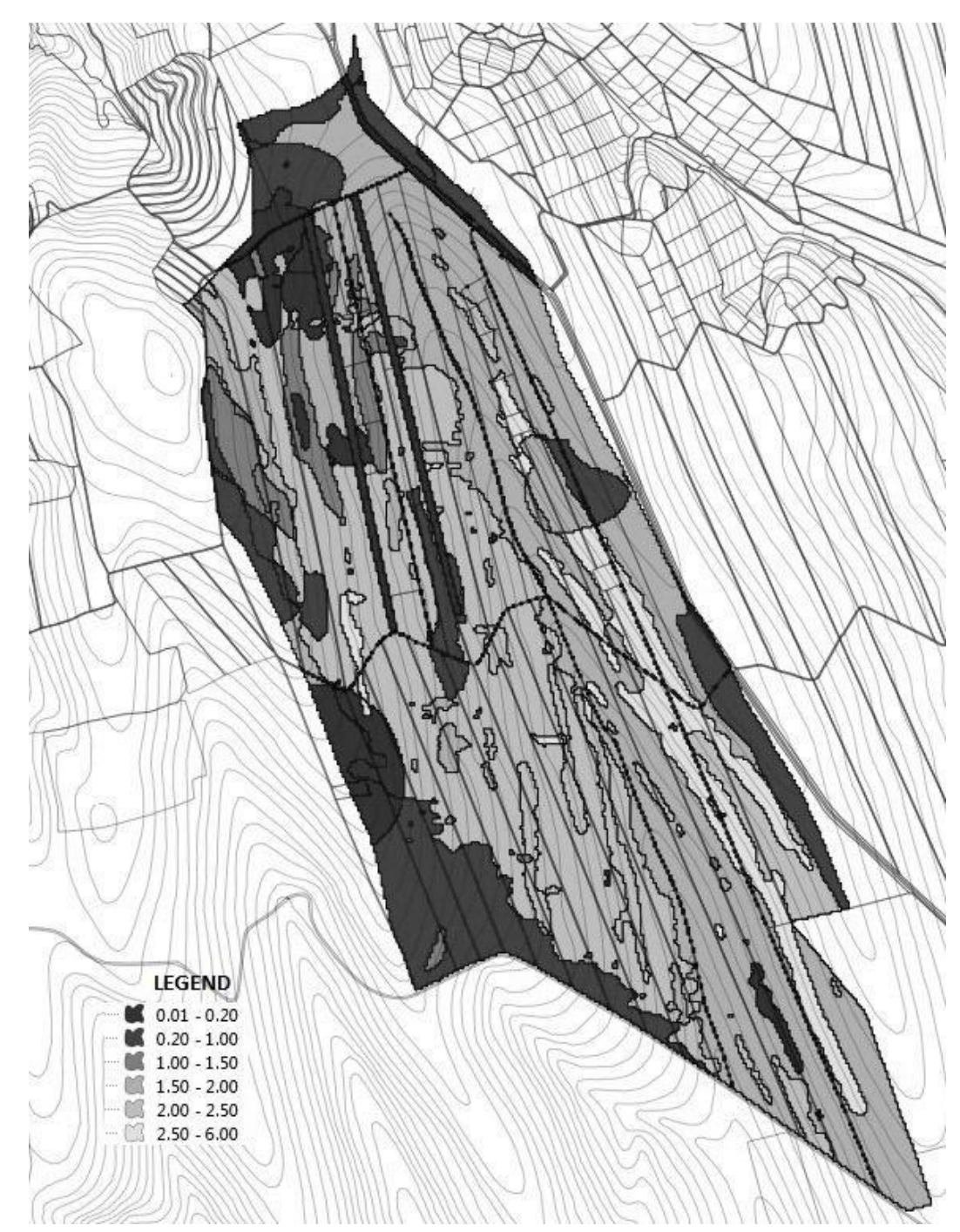

Figure 8. Soil loss distribution calculated by RUSLE module from Idrisi Andes software

Regarding the soil loss, it can be noted in Table 3 that the highest weight is the erosion between 1.5 and 2.5 t/ha/year, which corresponds to an area of approx. 360 ha $65.8 \%$ of the total Middle and Upper Tarnii Valley). These values are below the allowable value of 4-6 to/ha/year of erosion for the soil in the area.

Table 3. Categories of annual soil losses from Tarnii Valley calculated by RUSLE

\begin{tabular}{ccc}
\hline Erosion (t/ha/an) & Surface (ha) & $(\%)$ \\
\hline $0.01-0.20$ & 30.769 & 5.6 \\
$0.20-1.00$ & 95.235 & 17.4 \\
$1.00-1.50$ & 21.738 & 4.0 \\
$1.50-2.00$ & 187.861 & 34.3 \\
$2.00-2.50$ & 172.236 & 31.5 \\
$2.50-6.00$ & 39.313 & 7.2 \\
Total & 547.152 & 100.0 \\
\hline
\end{tabular}


In Figure 8 it can be noted that the most affected by erosion is the right hillside, which is the longest (in some areas, exceeding $1000 \mathrm{~m}$ length). In the middle, this hillside has an average erosion of about $2.5 \mathrm{t} / \mathrm{ha} / \mathrm{year}$, while values of erosion on the left side were 1.5-2.0 t/ha/year on most of the surface, except for some small areas with steep slopes, where erosion reach values of about. $3.5 \mathrm{t} / \mathrm{ha} / \mathrm{year}$. It also points out the special influence of the forest belts, (about $10 \mathrm{ha}$ ) where erosion does not exceed $0.02 \mathrm{t} / \mathrm{ha} /$ year. The lowest values of erosion ( 0.01 to $1.5 \mathrm{t} / \mathrm{ha}$ /year) can be found on approx. 17 ha, obviously, in the watershed where the slope is very low. As a general matter, we note how erosion is influenced by slope, slope length and soil texture unevenness, but the most important is the contribution of soil conservation measures.

\section{Conclusion}

- In Tarnii Valley, Romania, studies on runoff plots over a period of 29 years showed that the maximum values of total runoff and erosion correspond to rainfall between 10 and $30 \mathrm{~mm}$ as well as for the exceptional rains exceeding $50 \mathrm{~mm}$ for almost all crops analyzed.

- The crop structure from the analyzed basins which allowed the realization of a good vegetal cover, contributed significantly to diminishing of runoff and erosion processes.

- In Tarnii Valley, the most important soil losses were caused by the pattern of the microrelief formed many years ago when the tillage was usually executed following the up-and-down hill direction, eventhough a complex system of soil conservation practices was subsequently applied.

- The values of soil losses in studied areas where a wide range of soil conservation measures have been applied were generally below the allowable value of 4-6 to/ha/year of erosion corresponding to soils from Barlad Tableland.

\section{References}

Brakensiek, D.L., Osborn, H.B., Rawls, W.R., 1979. Field Manual for Research in Agricultural Hydrology, Agricultural Handbook 224, U.S. Department of Agriculture, U.S. Government Printing Office, Washington, DC.

Foster, G.R., McCool, D.K., Renard, K.G., Moldenhauer. W.C., 1981 - Conversion of the universal soil loss equation to SI metric units. Journal of Soil and Water Conservation 36(6): 355-359.

Hudson N.W., 1993. Field measurement of soil erosion and runoff. Edited by Silsoe Asociates Ampthill, Bedfort, United Kingdom.

Renard, K.G., Foster, G.R., Weesies, G.A., McCool, D.K., Yoder, D.C., 1997, Predicting Soil Erosion by Water: A Guide to Conservation Planning With the Revised Universal Soil Loss Equation (RUSLE), Agricultural Handbook, 703. U.S. Government Printing Office, Washington, D.C. 404 pp.

Toit .J., Foster, G.R., Renard, K.G., 2002. Soil erosion: prediction, measurement, and control. Edited by J.Wiley\&Sons, Inc., New York, USA.

Wischmeier, W.H., Smith, D.D., 1978. Predicting Rainfall Erosion Losses - A Guide to Conservation Planning. USDA, Washington DC. 